\title{
Donor Obligation for Public Sector Reform in Nepal
}

\author{
Ganesh P. Adhikari, PhD \\ Associate Professor of Public Administration in Tribhuvan University \\ Nepal \\ E-mail: gpadhikari@pactu.edu.np
}

Received: August 07, 2012 Accepted: September 17, 2012 DOI: 10.5296/jpag.v2i3.2471

\begin{abstract}
Donor obligation is the donor role expected by the recipient. As a developing country, Nepal is characterized by the inadequate governance. As a result of the globalization of governance, Nepal has been making efforts for improving governance mostly supported by donor agencies since 1990s. In this context, this paper aims to assess the necessity of donor-support for improving democratic governance; to analyze the appropriateness of donor-support for civil service reform; and to identify the level of efficiency of development actors in demonstrating good governance in Nepal.

This article is heavily based on secondary data. However, the data related to the 'appropriate donor-support for civil service reform' are derived from secondary analysis based on the raw data collected during the researcher's own PhD work (Adhikari, 2011). The study reveals that the donor-support is highly necessary for strengthening local authorities and civil society organizations. Financial support and policy advice are necessary for strengthening local authorities - the best performers of good governance among development actors in Nepal. Only policy advice is required for reforming new areas of civil service such as merit-based bureaucracy and performance incentives. The highly complex issue of civil service reform is corruption control in Nepal for which all kinds of donor-support (policy advice, financial advice and technical assistance) are required in Nepal.
\end{abstract}

Keywords: Success Story, Factor Analysis, Business Excellence, Bahrain, Public Administration 


\section{Public Sector Governance in Nepal: An Overview}

Public sector governance refers to the governmental institution that includes a network of donor-recipient as well as public-private partnership and a set of rules and regulations for managing public affairs under the paradigm of inclusive democracy. This section devotes to describe the causes of inadequate governance, efforts for improving governance and to review donor support for reforming governance.

\subsection{Causes of Inadequate Governance}

In Nepali context the causes of poor governance can be viewed from two dimensions: (i) administrative culture; and (ii) political and economic situation. For understanding the administrative culture from a theoretical perspective, it is relevant to view Nepal from Rigg's model. From Rigg's perspective, the Nepali society could be considered as a prismatic society that is neither fused (traditional) nor diffracted (modern). Nepal as a prismatic society, it is characterized by formalism, heterogeneity, overlapping of organizational structures, nepotism, and poly-communalism. Because of being a developing country, Nepal's administration is characterized by a discrepancy between prescriptive and descriptive, between formal and effective power, between the impression given by the constitution, laws and regulations and the actual practices (Prasad and Manohar, 1991). Such discrepancy is also known as formalism. This theory indicates that the crisis of governance is a key feature of prismatic society like Nepal.

Dhungel and Ghimire (2000) highlighted several cultural traits of Nepali administrative culture as the cause of poor governance. To them, Nepali administrative culture is characterized by feudal structure of bureaucracy, patron-client relationship in service delivery, nepotism and favorism, Chakari (buttering), buck passing, unnecessary secrecy, recognition of corrupt behavior, risk avoidance, distorted role perception, process orientation, absence of enthusiasm, and double standard (the gap between preaching and practice).

Another dimension of the causes of poor governance in Nepal is its political and economic situation. To United Nations System (UNS, 1999), the main reason of inadequate good governance in Nepal was the climate of continuous political instability. Nepal had conducted four parliament elections after 1990: in 1992, 1994, 1999, and 2008. No government was run in full term. To DFID/Nepal (2005), the main causes of poor governance in Nepal were poverty, social exclusion, wide spread corruption and Maoist insurgency.

\subsection{Efforts for Improving Governance in Nepal}

After the restoration of democracy, the constitution of the Kingdom of Nepal was promulgated in 1990 that guarantees a multiparty policy, a constitutional monarchy, people's sovereignty and fundamental human rights. The constitution recognizes the importance of decentralization, the equitable distribution of economic resources, the rights and welfare of children and the upliftment of economically and socially deprived communities. In practice, however, a great deal remains to be done for translating these clauses into reality. 
In the spirit of the democratic constitution, several legal Acts were passed and institutions created for improving governance in Nepal. They were: (a) Karya Bibhajan Niyamabali 2047 (Business Allocation Rules 1990); (b) Karya Sampadan Niyamabali 2047 (Transaction of Business Rules 1990); (c) Administrative Reform Commission 1991; (d) Civil Service Act 1993; (e) Civil Service Regulations 1993; (f) Civil Service Reform Act 1994; (g) Human Rights Commission Act 1996; (h) Human Rights Commission 1999; and (i) Local Self-Governance Act 1999.

The council of ministers is responsible for directing, controlling and regulating the country. The council of ministers has to conduct the government business on the basis of two rules-Karya Bibhajan Niyamabali that allocates the functions for different ministries and the Karya Sampadan Niyamabali, though confidential, defines the working procedure of cabinet, ministers and constitutional bodies.

In 1991, a high level Administrative Reform Commission was formed under the chairmanship of the Prime Minister Girija Prasad Koirala. The report of this commission was devoted to recommend on efficient, economical and people-oriented governance system and more specifically in the line of "reinventing government".

For reforming civil service, Civil Service Act was passed in 1993, Civil Service Regulations in 1994 and Civil Service Reform Act in 1994. Similarly for improving human rights, Human Rights Commission Act was passed in 1996 and the Human Rights Commission was created in 1999.

Several donor agencies including United Nations System (UNS, 1999) appreciated the Local Self-Governance Act 1999 considering it as a significant breakthrough in reducing administrative inefficiencies and promoting decentralization or for empowering local authorities. But, Shrestha (2000) concludes that the Local Self-Governance Act 1999 is just an "old wine in a new bottle", because it is just a compiled single volume of three separate Acts of local bodies-VDC Act, DDC Act and Municipality Act-promulgated in 1991. However, the Local Self-Governance Act aims at strengthening local institutions in terms of financial autonomy, making them directly accountable to people.

Apart from making legal provisions and creating institutions, the Government of Nepal has also incorporated policy issues of governance reform in its development plans. The Ninth Plan (1997-2002) is the first plan document in pronouncing the policy of governance. The plan contains a separate chapter on good governance and management. The Tenth Plan (NPC, 2003) document appreciates the Ninth Plan's progress in policy reforms in the areas of decentralization, civil service reform, corruption control, tax reform, public expenditure reform, financial sector and infrastructure reform. These reforms are also incorporated in the Tenth Plan (NPC, 2003).

Decentralization: To create a legal framework of decentralization, the Local Self Governance Act was enacted in 1999. To reform institutional framework, a high level Decentralization Implementation Monitoring Committee (DIMC) was set-up. 
Civil Service Reform: To make the civil service more results oriented as well as people oriented, a long term Governance Reform Program (GRP) was initiated. For right-sizing the civil service, the Government of Nepal froze more than 12000 vacant positions during the Ninth Plan period.

Corruption Control: For addressing corruption practices, "four anticorruption legislation were passed by the Parliament ....[and] a Judicial Property Probe Commission was also established" (NPC, 2003:18).

Tax Reform: For improving revenue collection, a Value Added Tax (VAT) was introduced and Income Tax Act was revised. For strengthening tax administration, The Departments of VAT and Taxation was amalgamated into one.

Public Expenditure Reform: A Public Expenditure Review Commission (PERC) submitted its comprehensive report to the Finance Minister in 2001. PERC recommended, among others, to formulate Medium Term Expenditure Framework (MTEF) that was adopted in the budget of fiscal year 2002/03. Government has formed various task forces to look into implementing the recommendations made by the PERC (ESP, 2001).

Financial Sector: For reforming financial sector, a Financial Sector Strategy Statement (FSSS) was prepared in 2001. The reform programs of FSSS are now (during $10^{\text {th }}$ plan period) being implemented to strengthen autonomy of the Nepal Rastra Bank and to place two major commercial banks under external management.

Infrastructure Reforms: Some of the reforms were initiated in the Ninth Plan (1997-2002) period to encourage private sector participation in infrastructure, particularly in power, telecommunications, education, health, and rural infrastructure (NPC, 2003).

The important reform initiatives taken during the study period include: allowing the private sector entry in the generation, transmission, and distribution of hydro-power; opening of the telecommunication sector for private investment; providing alternative educational and health care services through private sector and improving service delivery through community participation and management; creating a separate institutional mechanism (i.e. Department of Local Infrastructure Development and Agriculture Road) and formulating a Public Infrastructure Construction and Transfer Policy to promote private sector participation for constructing local roads; and distributing fertilizer and seed through private sector.

In recent years, the governance reform has become a matter of discussion also in Nepal Development Forum (NDF). In NDF-2002, the Government of Nepal strongly committed to making public-sector management lean, transparent, competitive, economical, efficient, service-oriented, accountable and more gender-sensitive (NDF, 2000). In the meeting, the donor representatives also addressed the issue of "a crisis of governance" in Nepal. In response, the Government of Nepal committed to reduce poverty, improve its planning, budgeting and expenditure management, effectively implement programs, and improve accountability and transparency. 
The Ministry of Finance committed to focus on the then ongoing reforms in the Nepal Development Forum 2004, particularly public expenditure reforms, tax reforms, public enterprise reforms, private sector development, financial sector reforms, decentralization, improving financial management and accountability, improving budgeting and expenditure management, civil service reform and sector-specific reforms (FACD, 2004).

\subsection{An Overview of Donor-Support in Governance Reform}

Bhatta (2000) explicitly states that good governance emerged in the late 1980s as a new paradigm which was dictated by the international agencies led by the World Bank. Governance reform has been considered a path to economic growth and poverty reduction. This is the reason why donors want to assist for reforming governance. Several donor agencies have had been involved in supporting Nepal for her governance reform as given below:

Table 1: Donor Partners Involving in Governance Area

\begin{tabular}{|l|l|l|}
\hline Governance area & Multilaterals & Bilaterals \\
\hline Civil service reform & $\begin{array}{l}\text { WB, ADB, UN } \\
\text { Agencies }\end{array}$ & UK, Switzerland \\
\hline Anti-corruption & ADB & Denmark, Norway, Switzerland, UK \\
\hline Decentralization & $\begin{array}{l}\text { WB, ADB, UN } \\
\text { Agencies }\end{array}$ & $\begin{array}{l}\text { Canada, Denmark, Germany, Netherlands, } \\
\text { Norway, Switzerland, UK, US }\end{array}$ \\
\hline Human rights & - & Canada, Denmark, Norway Switzerland, UK \\
\hline Social inclusion & $\begin{array}{l}\text { WB, ADB, EU, UN } \\
\text { Agencies }\end{array}$ & $\begin{array}{l}\text { Canada, Denmark, Germany, Netherlands, } \\
\text { Norway, Switzerland, UK }\end{array}$ \\
\hline $\begin{array}{l}\text { Integrated security } \\
\text { development }\end{array}$ & - & US \\
\hline
\end{tabular}

Source: World Bank (2004: 49).

Table 1 shows that, among bilateral donors, there is predominance of European donors. They are: Denmark, Germany, Netherlands, Norway, Switzerland and UK. Non-European donors implementing governance-related projects were only Canada and US. Among multilaterals, ADB, World Bank and UN Agencies have been involving in almost all areas of governance. But the World Bank and ADB focus on macro-level governance whereas the UN Agencies focus on local governance.

United Nations System (UNS, 1999) aims to assist Nepal government in governance improvement particularly in decentralization, capacity-building of local institutions, and empowerment of disadvantaged groups. It means the UN Agencies want to focus on local governance. The widely known example is the Local Governance Program (LGP) supported by UNDP. The UNDP is a lead donor for coordinating all the donors involved in local governance and decentralization. 
For both multilateral and bilateral donors, the UK is a lead donor in the field of good governance including administrative reform. In the field of democratic governance including judicial reform, Denmark is the lead donor in Nepal (ODI, 2000). The role of leading donors is to coordinate other donor partners involved in the concerned field. They not only help in donor-donor coordination but also serve as a focal point of the government to deal with in the concerned field.

After promulgating the Local Self-Governance Act in 1999, many donors have shown their interest in supporting Nepal's efforts in decentralized decision-making. UNDP involved in the decentralized management of local development by implementing its Participatory District Development Program (PDDP) in 20 districts. A local trust fund has been established in each participating district for ensuring financial sustainability. DANIDA also involved in decentralized policy reforms. Likewise GTZ, USAID, FINNIDA and NORAD are involved in supporting Nepal's initiative in decentralized decision-making by implementing different projects (FACD, 2005).

Almost all the constitutional bodies in Nepal are also reformed by donors. DFID reformed 4 constitutional bodies-Public Service Commission (PSC), Commission for Investigation of Abuse of Authority (CIAA), Prime Minister's Office (PMO), and National Planning Commission (NPC) - by implementing the projects: Nepal NPC project, CIAA Institutional project, PMO project, and support to NPC respectively during the second half of the 1990s. The reforms were aimed at improving their functions. For example, for improving the functions of Public Service Commission, the objective of the project was to improve the selection, recruitment and promotion procedures within the civil service (UNDP, 2000).

The DANIDA also helped reform Parliament Secretariat, and Election Commission by implementing the projects: support to the Parliament Secretariat and support to Election Commission. Likewise the World Bank reformed NPC by executing the NPC strengthening project. UNDP also executed "Reform of the Judiciary" project (2000-2005) to support the strategy Government of Nepal the by addressing some key issues related to rule of law and judiciary and to enhance access to and improve the quality of justice for all citizens and particularly women and members of disadvantaged group (FACD, 2005). The project beneficiary was Supreme Court, a constitutional body.

The World Bank has supported Nepal's Poverty Reduction Strategy (PRS) paper by implementing two projects-Poverty Reduction and Growth Facility (PRGF) and Poverty Reduction Support Credit (PRSC). The key components of these projects are: financial sector strengthening, public sector reforms, governance reforms including service delivery improvements and social inclusion promotion (FACD, 2005).

The ADB has also supported the implementation of PRS by implementing a project "Public Sector Management Program". The aim of this project was to strengthen the fiscal position of the government, disengage the government from the public enterprise management and ownership, and strengthen public and private sector governance (FACD, 2005) 
The DFID (2005:14-15) funding policy focuses on (i) improving public expenditure management and privatizing state-owned enterprises, (ii) decentralization and sectoral devolution, (iii) combating corruption, and access of justice. Much of its support is directed through Enabling State Program (ESP) which runs several projects for reforming governance in Nepal.

Thus, most of the development projects and programs undertaken after the mid-1990s are implicitly related to governance reform. The reason behind it is that the governance has become a cross-cutting issue of development since the early 1990s. In some cases, governance reform has also been projectized. In most cases, it is difficult to segregate purely governance-related projects from among all donor-funded projects. However, a Development Cooperation Report (FACD, 2005) presents a list of some selected projects related to rule of law and good governance.

Among the governance related projects, the ADB funded "Governance Reform Program" was the largest project in terms of the amount of aid. The second largest program is Enabling State Program of DFID that aims at developing practical understanding of good governance in the country. It focuses mainly on pro-poor governance. The committed amount for these two programs was more than NRs 20 billion each. But the ADB committed loan assistance and DFID grant. In some cases, ADB also provided grant, for example, for "Strengthening Rule of Law".

A single project of UNDP was not as large as that of ADB and DFID. But UNDP provided more aid than any other donors, for governance reform, by launching several projects-(i) Enhancing Access to Justice through Media Campaign, Settlement Fairs and Strengthening Community Mediation Practice; (ii) Human Rights Based Approach to Programming with special Focus on Conflict; (iii) National Human Rights Action Plan; (iv) Strengthening Rule of Law; (v) Coordination and Support of International Electoral Observers; and (vi) Local Governance Program. The largest project of UNDP was "Local Governance Program". The objective of this project was to strengthen and support decentralized, participatory and sustainable management of local development and to strengthen the planning and management capacity of DDCs and VDCs (FACD, 2005).

The USAID has also contributed in this field by implementing projects such as: Anticorruption and Law Enforcement, and Specialized Project for Promoting Peace through Improved Governance and Income in Target Areas. The objective of former project was to strengthen rule of law and of later was to mitigate the conflict in Nepal through support for the provision of quick and visible benefits to the under-served and conflict affected populations, and through support for peace process (FACD, 2005).

DANIDA, SNV, NORAD and SDC have also contributed in the field of local governance, human rights, and good governance. Among their projects, the DANIDA's "Human Rights Good Governance" is the largest one. The objectives of this project are: (i) to create effective public awareness on human rights, victims of human rights; (ii) to support abused victims; (iii) to mitigate and resolve social conflicts; (iv) to create a strong broad based democratic 
organizations of Dalits; (v) to qualitatively improve the training of media practitioners in mastering the core score skills of journalism; and (vi) to strengthen the capacity and the necessary systems of the Election Commission for managing and conducting democratic elections (FACD, 2005).

On the whole, almost all donors have had been involving to support the effort of governance reform in Nepal. But the Nepal's one of the largest donors, Japan has not shown her interest in projectizing governance. But it does not mean that Japan has no interest in governance. Japan makes Nepal conscious in reforming governance through aid agreement paper aiming at improving the aid effectiveness. In fact, Japan has contributed to Nepal a lot for improving public sector governance through ADB.

\section{Necessity of Donor-Support for Governance Reform in Nepal}

The available literature on governance reform in Nepal reveals that, among the prominent donors working for public sector reform, European bilateral donors, Asian Development Bank, and United Nations Development Program focused on democratic governance, civil service reform, and good governance respectively (see: Adhikari, 2011). These three components of governance reform have been taken into consideration for this study even though they are not perfectly mutually exclusive.

\subsection{Necessity of Donor-Support for Democratic Governance}

This section assesses the extent of the necessity of donor-support for improving democratic governance in Nepal. For this purpose, 11 issues of democratic governance were set as given below:

Strengthening Local Authorities: Almost all the donors working in Nepal have been funding for strengthening local authorities. Some of the prominent examples of on-going donor-funded projects during the study period were: "Decentralization Support Unit" supported by DANIDA; "Local Governance Program" supported by UNDP; and "District Partnership Program” supported by SNV (see Adhikari, 2011).

Strengthening Civil Society Organizations: After the restoration of democracy, the number of NGOs, professional organizations, trade unions, religious groups, and media has increased substantially. The number of NGOs registered at the Social Welfare Council increased from 5,128 in January 1997 to more than 10,475 by March 2000 (ESP, 2001). Most of them are not in action; some of them are affiliated to political parties; some are created by donors and INGOs. However, they have become important development actors.

Controlling Corruption: Major governmental organizations for controlling corruption in Nepal are: Commission for the Investigation and Abuse of Authority (CIAA), Special Police Department, District Administration Offices, Judicial Council, and Revenue Investigation Department (see ESP, 2001). If these institutions are reformed then corruption will be reduced. By considering this assumption, several donor-funded projects were implemented 
for this purpose (see Appendix E).

Strengthening Private Sector: Since 1992 the Government of Nepal has adopted a policy of private sector development for liberalizing economy by regulating rather than controlling the private sector. Several policies- trade, industrial, financial, foreign investment, privatization were reformed. Several donor-funded projects were implemented in Nepal (see Appendix E). Some of the key informants were of opinion that the implementation part of private sector reform was very weak in Nepal mainly because of the reluctancy in bureaucrats and poor political commitment.

Strengthening Governmental Institutions: The term 'governmental institutions' refers to the set of rules, regulations, practices, and administrative culture of executive, legislative, judiciary and other publicly-owned governmental organizations. Several donor-funded projects were implemented for reforming central level governmental organizations in Nepal (see section 6.1).

Reforming Development Policies: "Reforming development policies" refers to the change in development approaches, strategies, goals, procedures and practices in the line of modern governance or neo-liberalism. In micro-level, it includes specific procedures like project formulation, procurement, auditing, evaluation and reporting of donor-funded projects. An example of such project is "Strengthening Project Implementation and Quality Assurance Project". It was funded by ADB in 2004.

Reforming Civil Service: After 1990, the concept of civil service reform is viewed from the perspective of good governance such as improving accountability, transparency, effectiveness, responsiveness, and inclusive civil service. One of the most popular donor-funded programs of civil service reform in Nepal was "Governance Reform Program" initiated by ADB's loan in 2001.

Improving Human Rights Situation: After mid-1990s, a new paradigm of 'rights-based development' emerged. It focuses on promoting human rights in the development process (Uvin, 2004). In this context, donor agencies have been showing their interest in aligning national laws with international human rights standards and commitments. For example, UNDP implemented a project "National Human Rights Action Plan", DANIDA implemented "Human Rights and Good Governance", and NORAD implemented "Implementation of Human Rights and Good Governance Program” since 2003.

Improving Rule of Law: The most important value of democracy is Rule of Law- the independent and competent system of justice. Nepali citizens experienced a situation of law-less-ness during the course of Maoist insurgency. Government was unable to maintain law and order and protect human rights. In some cases the ruling parties protected criminals involved in serious crimes (ESP, 2001).

Strengthening Political Parties: After the restoration of multiparty democracy in 1990, major political parties have been developing their institutional capacity from their own effort. The 
process of dissolution and reorganization of parties was occurred frequently. Some key informants asserted that no political party developed a democratic culture and ideological clarity with a long term vision. It reveals that the 'strengthening political parties' is highly necessary.

National Election: In many cases, election funding to political parties from certain embassies had becoming a confidential issue for many years in the past. In Nepal, a major funding source of political parties was from illegal activities such as smuggling, drug trafficking, illegal trading, and the commission of development projects (ESP, 2001:8). In 2002, a project entitled "Coordination and Support of International Electoral Observes" supported by UNDP was implemented.

The ranking of the above discussed issues of democratic governance on the basis of their weighted mean score is as given below.

Table 2: Democratic Governance: Necessity of Donor-Support

\begin{tabular}{|l|c|c|c|c|}
\hline \multirow{2}{*}{ Issues of democratic governance } & \multicolumn{3}{|c|}{ Necessity of donor support (n=225) } \\
\cline { 2 - 5 } & $\begin{array}{c}\text { Highly } \\
\text { necessary } \\
(2)\end{array}$ & $\begin{array}{c}\text { Necessary } \\
(1)\end{array}$ & $\begin{array}{c}\text { Not } \\
\text { necessary } \\
(0)\end{array}$ & $\begin{array}{c}\text { Weighted } \\
\text { mean score }\end{array}$ \\
\hline Strengthening local authorities & $56 \%$ & $44 \%$ & $0 \%$ & 1.56 \\
\hline $\begin{array}{l}\text { Strengthening civil society } \\
\text { organizations }\end{array}$ & $33 \%$ & $64 \%$ & $3 \%$ & 1.30 \\
\hline Controlling corruption & $34 \%$ & $56 \%$ & $10 \%$ & 1.24 \\
\hline Strengthening private sector & $29 \%$ & $46 \%$ & $24 \%$ & 1.04 \\
\hline Strengthening governmental institutions & $28 \%$ & $46 \%$ & $27 \%$ & 1.02 \\
\hline Reforming development policies & $19 \%$ & $60 \%$ & $21 \%$ & 0.98 \\
\hline Reforming civil service & $27 \%$ & $42 \%$ & $31 \%$ & 0.96 \\
\hline Improving human rights situation & $22 \%$ & $47 \%$ & $31 \%$ & 0.92 \\
\hline Improving rule of law & $21 \%$ & $47 \%$ & $32 \%$ & 0.89 \\
\hline Strengthening political parties & $20 \%$ & $42 \%$ & $37 \%$ & 0.82 \\
\hline Assisting national election & $17 \%$ & $24 \%$ & $58 \%$ & 0.58 \\
\hline Total (percentage) & $28 \%$ & $47 \%$ & $25 \%$ & 1.03 \\
\hline
\end{tabular}

Source: Adhikari, 2011

The Table 2 shows that the donor-support for strengthening local authority is necessary in highest level because of its highest mean score i.e. 1.56. The respondents' second priority of donor-support is for strengthening civil society organizations.

\subsection{Appropriateness of Donor-Support for Civil Service Reform}

What kind of donor-support is appropriate for civil service reform in Nepal? For answering this question, 3 categories of donor-support - policy advice, financial support and technical 
assistance - and 7 issues of civil service reform were taken into consideration. The Table 6.3 shows the total response in favor of policy advice, financial support and technical assistance for different issues of civil service reform. More than 50 per cent respondents were in favor of all kinds of donor-support for corruption control. In case of strengthening local authority and citizen-centered service delivery, nearly 83 and 69 per cent respondents respectively were in favor of only financial support.

Table 3: Proportion of Positive Responses for Appropriate donor-support in the Issues of Civil Service Reform

\begin{tabular}{|c|c|c|c|c|}
\hline \multirow[t]{2}{*}{ Issues of civil service reform } & \multicolumn{3}{|c|}{$\begin{array}{l}\text { z-value of the proportion of responses } \\
\qquad(\mathrm{n}=225 \text { for each cell })\end{array}$} & \multirow{2}{*}{$\begin{array}{c}\text { Grand total of } \\
\text { positive } \\
\text { responses } \\
\text { (out of } 675 \text { ) } \\
\end{array}$} \\
\hline & $\begin{array}{l}\text { Policy } \\
\text { advice }\end{array}$ & $\begin{array}{l}\text { Financial } \\
\text { Support }\end{array}$ & $\begin{array}{l}\text { Technical } \\
\text { Assistance }\end{array}$ & \\
\hline Strengthening local authority & $\begin{array}{r}0.600 \\
(52.0) \\
\end{array}$ & $\begin{array}{r}9.800 * * * \\
(82.6) \\
\end{array}$ & $\begin{array}{r}-3.800 \\
(37.3) \\
\end{array}$ & 387 \\
\hline Corruption control & $\begin{array}{r}2.067 * * \\
(56.9) \\
\end{array}$ & $\begin{array}{r}2.200 * * \\
(57.3) \\
\end{array}$ & $\begin{array}{l}0.067 \\
(50.2) \\
\end{array}$ & 370 \\
\hline Citizen-centered service delivery & $\begin{array}{r}-3.400 \\
(38.7) \\
\end{array}$ & $\begin{array}{r}5.667 * * * \\
(68.8) \\
\end{array}$ & $\begin{array}{r}-0.733 \\
(47.5) \\
\end{array}$ & 349 \\
\hline Merit-based bureaucracy & $\begin{array}{r}1.000 \\
(53.3) \\
\end{array}$ & $\begin{array}{r}-1.133 \\
(46.2) \\
\end{array}$ & $\begin{array}{r}-0.067 \\
(49.8) \\
\end{array}$ & 336 \\
\hline Performance incentives & $\begin{array}{l}0.867 \\
(52.9) \\
\end{array}$ & $\begin{array}{r}-2.467 \\
(41.8) \\
\end{array}$ & $\begin{array}{r}-0.333 \\
(48.9) \\
\end{array}$ & 323 \\
\hline Procedural reform & $\begin{array}{r}-1.533 \\
(44.9) \\
\end{array}$ & $\begin{array}{r}-1.533 \\
(44.9) \\
\end{array}$ & $\begin{array}{r}-1.533 \\
(44.9) \\
\end{array}$ & 303 \\
\hline Social inclusion in civil service & $\begin{array}{r}-5.000 \\
(33.3)\end{array}$ & $\begin{array}{l}-6.200 \\
(29.3)\end{array}$ & $\begin{array}{l}-2.867 \\
(40.4)\end{array}$ & 232 \\
\hline
\end{tabular}

Note: $\mathrm{H}_{0}: \mathrm{p}=50 \%$; and $\mathrm{H}_{1}: \mathrm{p}>50 \%$

$* * *$ indicates level of significance at $1 \%$ level; *** at $5 \%$ level; and * at $10 \%$ level

Source: Secondary analysis of raw data collected by Adhikari (2011).

The Table 3 presents the observed $z$ values of the proportion of positive responses in three different types of donor-support in the given issues of civil service reform. In the issue of strengthening local authority, respondents were in favor of getting financial support rather than policy advice and technical assistance. The observed z-value of financial support is 9.800 which is significant because it is greater than the table value 2.326 at 1percent level in one-tailed test.

In the issue of receiving donor-support for controlling corruption, $\mathrm{H}_{0}$ is rejected at 5 per cent level of significance both in policy advice and financial support. It means that the respondents favored policy advice and financial support significantly. In the issue of 
citizen-centered service delivery, the majority of respondents were in favor of getting financial support, and it is true at 1 per cent level of significance.

The Table also indicates that all the tabulated $\mathrm{z}$-values in the issues of meri-based bureaucracy, performance incentive, procedural reform, and social inclusion in civil service are statistically non-significant.

\subsection{Efficiency of Development actors in Good Governance}

Which development actors have become efficient to demonstrate good governance in Nepal? For answering this question, 7 issues of good governance and 4 groups of development actors were taken into consideration and then respondents were asked to rank the development actors for the given issues of good governance. The following table presents the mean score of the performance ranking of development actors.

Table 4: Efficiency of Development Actors in Good Governance

\begin{tabular}{|l|l|l|l|l|}
\hline \multicolumn{1}{|c|}{ Issues of good governance } & \multicolumn{4}{c|}{$\begin{array}{c}\text { Mean score of the performance ranking of } \\
\text { development actors }\end{array}$} \\
\cline { 2 - 5 } & Donors & I/NGOs & GOs & Local authority \\
\hline a. Cost effectiveness & 1.94 & 2.58 & 2.76 & 3.63 \\
\hline b. Accomplishment in time & 2.89 & 2.60 & 1.66 & 3.02 \\
\hline c. Financial transparency & 2.10 & 2.44 & 2.76 & 3.61 \\
\hline d. Minimization of Corruption & 2.23 & 2.38 & 2.53 & 3.25 \\
\hline e. Accountability (to user group) & 1.56 & 2.13 & 2.80 & 3.23 \\
\hline f. Participation of stakeholders & 2.08 & 3.13 & 2.54 & 3.63 \\
\hline g. Local capacity-building & 1.73 & 2.43 & 2.58 & 3.32 \\
\hline Average score & 2.07 & 2.55 & 2.52 & 3.34 \\
\hline
\end{tabular}

Note: The highest score is 4 for best performer and 1 for least performer $(n=225)$.

Source: Adhikari, 2011.

The Table 4 indicates that the respondents considered local authority as being best performer and donors as being least performer to demonstrate good governance. The mean scores assigned to I/NGOs and GOs are in between the scores of donors and local authorities. It is also important to note that the average 'mean score values' range from 2.07 of donor agencies to 3.34 of local authorities. It seems a high level of variation in the efficiency of development actors for demonstrating good governance. The lowest level of donor efficiency indirectly indicates that the turn-key projects executed by donor agencies are not effective in terms of good governance, particularly from recipient's perspective. 


\section{Conclusion and Suggestions}

The main causes of inadequate public sector governance are feudal structure of bureaucracy, political instability, poverty, and wide spread corruption. Government of Nepal has been making efforts for improving governance in Nepal since the early 1990s. Several governance-related laws were passed, institutions were created, and governance-focused plan documents were prepared. The World Bank, ADB, UN Agencies, and European bilateral donors supported several governance reform programs in Nepal. However, the donor-funded reform programs are not being sufficiently sustaining may be due to several factors, such as political instability, lack of the country-ownership of aid activities, and corruption.

With regard to the necessity of donor-support for democratic governance, the respondents were of opinion that the donor-support is highly necessary for strengthening local government and civil society organizations. Similarly the aid is not highly necessary for assisting national election, strengthening political parties, improving rule of law, improving human rights situation, reforming civil service, and reforming development policies.

Regarding the civil service reform, respondents gave their views on the appropriate type of donor-support. More than 50 percent respondents were in favor of financial support and policy advice for strengthening local authority. They were in favor of policy advice, financial support, and TA for corruption control; financial support for citizen-centered service delivery; and policy advice for merit-based bureaucracy, and performance incentives.

Regarding good governance, respondents considered local authority as being the best performer, donors as being least performer, and I/NGOs and GOs as being moderate performer for demonstrating good governance particularly in the issues of cost-effectiveness, accomplishment in time, financial transparency, minimization of corruption, accountability to user groups, participation of stakeholders, and local capacity-building.

On the whole, the findings of the study indicate what should be done by the government as well as donor partners for reforming public sector in Nepal. The Government of Nepal should go ahead for political stability and country-ownership of aid activities through capacity building. The donor partners should focus on strengthening local authorities civil society organizations. Donor agencies should also rethink the appropriateness of their policy advice, financial support and technical assistance by considering local needs in different issues of governance reform, such as controlling corruption, improving human rights situation and reforming civil service. On the other hand, donor agencies should reduce their support in less important issues, such as assisting national election and strengthening political parties.

\section{References}

Adhikari, G.P. (2011). The Politics of Foreign Aid and Governance Reform in Nepal. An unpublished $\mathrm{PhD}$ thesis submitted to the Faculty of Management, Tribhuvan University, Nepal. 


\section{Macrothink}

Journal of Public Administration and Governance ISSN 2161-7104 2012, Vol. 2, No. 3

Bhatta, B.D. (2000). "Decentralization in the Context of Good Governance and Civic Society in Nepal". In Public Administration Journal, vol. x \& xi, (pp. 368-375). Kathmandu: Public Administration Campus.

DFID (2005). Annual Report. Kathmandu: Department for International Development, Available at www.dfid.gov.uk.

Dhungel, D.N. and Ghimire, H. (2000). Demands for a New Culture in the Context of Good Governance. A theme paper presented in the Sixth National Convention of Public Administration Association of Nepal.

ESP (2001). Pro-Poor Governance Assessment in Nepal. Nepal: Enabling State Programme.

FACD (2004). Chairman's Summary of the Proceedings of Nepal Development Forum 2004. An unpublished report prepared by Foreign Aid Coordination Division, Ministry of Finance, Nepal.

(2005). Development Cooperation Report 2001-2004. Nepal: Foreign Aid Coordination Division, Ministry of Finance.

NDF (2002). "Review of Development Partnership in Nepal". A paper prepared by donors group led by OECD (not mentioned in the report) and presented at the Nepal Development Forum 2002.

NPC (2003). The Tenth Plan 2002-2007: Summary. Nepal: National Planning Commission. Commission.

(2007). Three-Year Interim Plan (2007-2010). Nepal: National Planning (2010). Three-Year Plan: Approach Paper (2010/11-2012/13). Nepal: National Planning Commission.

ODI (2000). European Aid for Poverty Reduction in Nepal. London: Overseas Development Institute.

Prasad, V.S. and Manohar, K.M. (1991). "Fred W. Riggs". In D.R. Prasad et al., eds., (1991), Administrative Thinkers, (pp. 234-260). New Delhi: Sterling Publishers Pvt. Ltd.

UNS (1999). Nepal: Common Country Assessment 1999. Nepal: United Nations System.

World Bank (2004). Nepal: Country Assistance Strategy, 2004-2007. Kathmandu: The World Bank. 